\title{
The "In-Between" Intercultural Knowledge Production: A Case Study from the Teacher Training Kaingang Ethnicity in Southern Brazil
}

\author{
Miguel Ângelo Silva da Costa ${ }^{*}$, Luci dos Santos Bernardi' ${ }^{1}$ Leonel Piovezana1, \\ Luzane Mores Bernardi² \\ ${ }^{1}$ Department of Education, Universidade Comunitária da Região de Chapecó, Chapecó, Brazil \\ ${ }^{2}$ Department of Mathematics, Universidade Comunitária da Região de Chapecó, Chapecó, Brazil \\ Email: ${ }^{*}$ miguel.costa@unochapeco.edu.br
}

Received 2 September 2014; revised 6 October 2014; accepted 18 October 2014

Copyright (C) 2014 by authors and Scientific Research Publishing Inc.

This work is licensed under the Creative Commons Attribution International License (CC BY). http://creativecommons.org/licenses/by/4.0/

(c) (i) Open Access

\begin{abstract}
As a reflection of an ongoing research project, whose wider scope of analysis focuses in the expectations and produced stares about indigenous education by students of Kaingang ethnicity enrolled in Graduation Bachelor Courses in Indigenous Intercultural Pedagogy, Mathematics and Sciences of Nature, all three offered by the Universidade Comunitária da Região de Chapecó (Unochapecó), this study problematizes to what extend the intercultural knowledge acquired over the training process of Kaingang indigenous teachers may be converted into reflections focused on their conceptions of education, (re) signification of their identity and autonomy within a context of an intense multiculturalism emergence as well as cultural hybridism, which characterize contemporaneity. The results indicate that, for those students, the intercultural knowledge may be triggering as an instrument of changes, inside and outside their communities; it strengthens and nourishes the debate around the role of formal education, the school and the indigenous teacher as a mediator between worldviews and cultures, in constant confluence.
\end{abstract}

\section{Keywords}

Intercultural Education, Indigenous Teacher, Kaingang Ethnicity, Sothern Brazil

\footnotetext{
${ }^{*}$ Corresponding author.
}

How to cite this paper: da Costa, M. Â. S. et al. (2014). The "In-Between" Intercultural Knowledge Production: A Case Study from the Teacher Training Kaingang Ethnicity in Southern Brazil. Creative Education, 5, 1936-1942. 


\section{Introduction}

The borderline work of culture demands an encounter with "newness" that is not part of the continuum of past and present. It creates a sense of the new as an insurgent act of cultural translation. Such art does not merely recall the past as social cause or aesthetic precedent; it renews the past, refiguring it as a contingent "in-between" space that innovates and interrupts the performance of the present. The "past-present" becomes part of the necessity, not the nostalgia, of living Bhabha (2003: p. 7).

Currently, a scenario in which our existence is marked by tenebrous feelings of living on the borders, or rather, in transitional social settings where "space and time are crossing and creating complex figures of difference and identity, past and present, interior and exterior, inclusion and exclusion” (Bhabha, 2003: p. 19), the mobilizing experiences with respect to the indigenous people and cultures have become part of a global public agenda embedded into the field of cultural hybridity. We can even say that in the sense of "nostalgia of difference" and the search for the construction of the supposed "authenticity" against the corruption of modern development, the indigenous cultures have not only be translated, but, also differentially absorbed the distinct and multiple cultural meanings assigned to processes of economic modernization and local modernisms (Gadea, 2007: p. 160).

The longstanding indigenous social issue in countries with Amerindian minorities, like Brasil, is collated by researchers from diverse academics areas. From different research fields and theoretical focuses, the academic production is wide and diverse. If returning to decade 1930, for example, certainly the debate would focus on opportunities for the physical survival of the indigenous groups and their gradual and fair integration into national society. The so-called "Brazilianization" of the indigenous groups, or rather, the integration policies emanating from the Indian state were linked to a larger project of nation-building as well as modernization of the country. These were also the goals advocated by the Indian Protection Service (SPI), an agency which was founded in 1910 and for a long time directed by Marechal Cândido Rondon, a positivist military who had been for years at the front of the Commissions of Telegraph Builders in Mato Grosso, a state located in the Center-West of Brazil. But not only that, the SPI, while under the Ministry of Agriculture, Industry and Commerce, in addition to its "civilizing" mission agency, also aimed the administration of the demarcation of the indigenous areas and indigenous man into the national economy, from its insertion as hand-work in the territories of the South and Midwest of the country, especially within the states of São Paulo, Paraná and Santa Catarina, which configured the advance of the called "agricultural frontier”. This integration project developed by indigenous SPI, whose bases were founded upon the tenets of modernity and construction of the modern nation, continued with the agency that replaced it in 1967, the National Indian Foundation (FUNAI) which was still in operation, despite the continuing crisis that affected social efficiency and political legitimacy.

However, since the 1930s the critical event related to the great “civilization" project for the indigenous integration into national society has contributed to the emergence of news discourses, demands and political-cultural initiatives in Brazil. Based on the right of diversity advocated by the Federal Constitution of Brazil in 1988, a considerable distance separates the model of rural schools, predominantly in Brazil until the mid-twentieth century, and the current specific schools and community education, installed in indigenous territories. This community school institution, which was intercultural, bilingual/multi-lingual and specific/differentiated, was qualified for the indigenous public as a New School, which also had to be understood as part of claims advocating new ways to establish relationships between different segments of society. Nevertheless, it should also be understood as a reflection of the so-called crisis of the disciplinary norm and homogenization of modernity. Given that, the normative discipline, before constituted by a set of institutional regulations and empirical processes dedicated to setting up a homogenized individual, demonstrated its weak-nesses, in example of the modernity and formal models of education. We can even consider that, in the face of a scenario marked by economic globalization and cultural globalization (Hall, 1997, 1999 and 2003; Bauman, 1998, 1999, 2001 and 2003), the critical reflection about indigenous education also "evidences a problematic socio-cultural and political issue regarding the relationship between the senses of current cultural challenges and normativism enclosed in teaching methods and educational programs” (Gadea, 2007: p. 177).

The intention of this article is presenting the partial results of a research project, which is focused on the analysis of expectations of the Kaingang indigenous students enrolled into Intercultural Graduation Degree courses offered by the Universidade Comunitária da Região de Chapecó (Unochapecó) about Indigenous School Education. Therefore, it is assumed that their expectations emerge in an in-between context, in which the repre- 
sentation of the difference cannot be read hastily as a reflection of cultural or ethnic predetermined features, but as part of a new emerging logic: the logic of mutable identity, or even better, the logic of constant redefinition of situations and experiences of political and cultural identification (Canclini, 1997). In particular, it discusses the extent to which intercultural knowledge is acquired within the formation of Kaingang indigenous teacher that can be converted into reflections aimed at their conceptions of education, identity (re)signification and autonomy in a context of intense emergence of multiculturalism and cultural hybridity, characterizing the contemporary.

\section{The Indigenus Kaingang Students of Unochapeco and Their Voices}

The template is used to format your paper and style the text. All margins, column widths, line spaces, and text fonts are prescribed; please do not alter them. You may note peculiarities. For example, the head margin in this template measures proportionately more than is customary. This measurement and others are deliberate, using specifications that anticipate your paper as one part of the entire journals, and not as an independent document. Please do not revise any of the current designations.

Belonging to Jê linguistic group, of Tronco Macro Jê, the Kaingang, ethnic group which come from the indigenous students enrolled in the course in Intercultural Graduation offered by Universidade Comunitária da Região de Chapecó (Unochapecó), totaling a population of approximately 37.400 individuals (2010 Census-IBGEBrazil). Although, contemporaneously, their villages are located in the regional space of the four states of southern Brasil (Rio Grande do Sul, Santa Catarina, Paraná e São Paulo), its historical and sociocultural process in the region and in adjacent areas, such as in Província de Misiones (Argentina), dates back two thousand years ago.

In Santa Catarina, estimated at 9.000 individuals, most of the Kaingang population lies established in the western region of the state, more specifically covered by the Indigenous Land Pinhal (city of Seara), ToldoImbu (city of Abelardo Luz), Indigenous Land Xapecó (cities of Ipuaçu and Entre Rios), Indigenous Land Chimbangue and Village Kondá (city of Chapecó) (Piovezana, 2007).

Established on indigenous lands Xapecó, Chimbangue and Village Kondá, indigenous academics of Unochapecó experience the dramatic effects of current social crises triggered by stories of cultural difference. If the recent past, deeply rooted to the violent actions of usurpation of their fields, or the abusive use of natural resources on their lands, the Kaingang established in Western Santa Catarina experienced contingencies resulting from the advance of the expanding frontiers of national society (Piovezana, 2007) currently, the new generations Kaingang faced with a scenario of intense social relations and cultural exchanges, the simple dualism between Kaingang and "his other" gives relief from the breakup of their ancestral culture.

Established on Indigenous Lands Xapecó, Chimbangue and Village Kondá, indigenous academics of Unochapecó experience the dramatics effects of current social crises triggered by stories of cultural difference. If the recent past, deeply rooted to the violent actions of usurpation of their domains, or the abusive use of natural resources on their lands, the Kaingang established in Western Santa Catarina experienced contingencies resulting from the advance of the expanding frontiers of national society (Piovezana, 2007) currently, the new generations of Kaingang are faced with a scenario of intense social relations and cultural exchanges, the simple dualism between Kaingang and "his other" gives relief from the breakup of their ancestral culture.

Contemporaneously, traditional Kaingang medicine granted space to modern medicine and allopathic medical treatment. New technologies-computers, internet, cell phones and televisions-as well as the infinity of Pentecostal and evangelist churches in Kaingang lands, are stark indicators of interchangeable identities embedded in between-a place, or if we are want, a space of moving boundaries (Skovsmose, Alro \& Valero, 2009).

This means that tradition and modernity are evident as interchangeable milestones in the Kaingang's life, therefore, are also significant and present experiences in the social aspects of the group of academics who, in 2009, started the Graduation Degree in Intercultural Indigenous, developed in Indigenous Land Xapecó with duration of ten (10) semesters and aiming to meet the indigenous communities of the region (Unochapecó, 2012).

In context, hence, of intense emergence of cultural hybridity and multiculturalism, how what characterizes the Kaingang contemporary, we can ask in what measure the intercultural knowledge acquired in the space of formation of this indigenous ethnicity can be converted into reflections aimed at their conceptions of education, identity (re)signification and autonomy? 
To answer this question and better systematize our arguments, we present here the speeches obtained from 24 indigenous academics (14 of Graduation Degree in Intercultural Indigenous Pedagogy and 10 of the Graduation Degree in Intercultural Indigenous Mathematics and Natural Sciences), methodologically organized from the application of questionnaires and interviews. With the aim of obtaining information about their expectations and looks about indigenous education, we organized their testimony based on three axes of emerging reflection from their own lines, thus organized (see Appendix): 1) the importance attributed to intercultural knowledge on the teacher training process (in Table 1) ; 2) the meanings conferred to intercultural education within the indigenous school (in Table 2); and 3) the mobilization of intercultural knowledge and their empowerment in emancipatory struggles (in Table 3). The words of the academics will be described in frames, where we chose to not identify their names.

\section{Results and Discussion}

Although preliminary, the analytical exercise proposed in this article allows us to infer that the proposals in indigenous intercultural undergraduate courses offered by Unochapecó, contribute to build a list of reflections not only of indigenous school education, as also of the broader struggles spearheaded by the Kaingang. The conceptions that underlie the statements of scholars are strongly influenced by the multiple choices present and built in in the set of cultural confluences with the world that surrounds them. When issuing their statements on the importance attached to intercultural knowledge in the teacher training process, leaves the impression that the quest for knowledge reflects part of a repertoire of strategies not necessarily devoted to simply better understand the world around them, but rather of it and interact with it consciously. The desire to "be a good professional able to educate and provide a quality education based on reality and popular knowledge of indigenous child, and why not also the non-indigenous” (Academic 01), denotes a future project built on this experience and his dialog with the liminality of the cultures that surround it. Is also in dialogue with this continuous flow of cultural interaction, which speaks of the Academic 03 is produced. When highlighting in his speech that the knowledge produced throughout the course translates into an "instrument of argument", the young native scholar suggests that, in addition to the endogenous environment of ancestral belonging to the group, intercultural perspective of teacher training underlies learnings that can also be triggered as legitimating strategies of Kaingang emancipation.

Regarding the meaning given to intercultural education within the indigenous school, scholars believe that the quality of their training, through indigenous intercultural degree course, can contribute to the construction of a less traumatic future for the new generations of Kaingang. The school, in this sense, is conceived as a space for knowledge building, valuing intercultural knowledge and reframing of roles. No wonder, in virtually all the stories/testimonials, indigenous intercultural education emerged conceived as "challenging” (Academics 24 and 03) as an instrument of "change" and social "fight" (Academics 12 and 18), in synthesis, also as an emancipatory perspective.

\section{Table 1. Emergent axis of reflection 01.}

1) The importance attached to intercultural knowledge during the teacher training process

Academic $01^{\mathrm{a}} \quad$ who is able to educate and provide a good quality education based on reality and popular knowledge of the indigenous child, and why don't say about the non-indigenous as well, I need only to prepare myself and I am sure I will be a good teacher, and over all, concerned with the quality education.”

Academic 03

"Through the course we construct a knowledge which is the instrument of argument in order to not to be fooled by the clever ones. Soon this knowledge will be socialized with our students.”

Academic 05

"In these four years I have learned a lot, acquired new knowledge to improve my attitudes in everyday life and especially in my field of work.”

Academic 10 "As a teacher, we have a very broad view. We learn to develop a good quality work in the field of education. Thus, by seeking for knowledge, we can transform our community and the surrounding society.”

\footnotetext{
${ }^{\mathrm{a}}$ Academic interviewed.
} 
Table 2. Emergent axis of reflection 02.

2) The meanings assigned to the intercultural education in the framework of the indigenous school

Academic Interviwed $\quad$ Speak of the Academic

it came ready, but suitable to changes and, we as indigenous academics and future teachers, are aware that it

Academic 01 needs to have distinctive characteristics and traditional education for indigenous communities [...]. It is perceived as essential the creating a pedagogical propose based on their own indigenous learning processes as well as their way of seeing the world."

"A school that meets the reality of the community, that fits their needs and is differentiated. Differentian
Academic $06 \quad$ with regard to autonomy as a right of the study of culture, customs, and who seeks the interaction of scientific knowledge and the knowledge of the culture.”

Academic $12 \quad$ "The group of academics of this course has the entirely vision of the rescue of the indigenous traditions, since we have learned to value our culture and fight for it.”

Academic 24 and everything we plant today will sow tomorrow. We are indigenous people who want to be heard, respected, and get valued our culture."

$\begin{array}{ll} & \text { "The necessary change is to have more qualified teachers in Indigenous schools. More support by the gov } \\ \text { Academic } 18 \quad \text { on the infrastructure, materials and teaching quality for the qualifications of professionals, and when I }\end{array}$ say professional, I mean everyone, not just teachers.”

Academic $04 \quad$ "Respect for the specific calendar on indigenous schools, more trained professionals, responsibles and with school engagement. An expansion of the number of classes of Kaingang teaching language.”

Academic 02 "Look, I always says that I grew up related to knowledge and matured my ideas and goals, and today I can say I'm on the right track, I want to be a teacher to help in the fight to rescue the culture of our people.”

Academic $07 \quad$ "The degree course came to contribute to my development as a teacher and also to teach us how to insert content related to our culture in the subjects worked in school, while teaching the universal learning.”

Academic 03 "It has helped a lot, since it challenges us to think about teaching from the culture and the quest for scientific knowledge. Every teacher must always be improving, seeking new information. The Indian degree is challenging, it makes us feel that we can go far beyond what we want.”

\section{Table 3. Emergent axis of reflection 03.}

3) The mobilization of intercultural knowledge and empowerment in emancipatory conflicts

Academic Interviwed Speak of the Academic

Academic 02 "We know it is not easy rescuing all we had, but the little that we manage behalf of our people would be satisfied."

Academic 19 "Seeking knowledge to transform our community and the surrounding society."

Academic $06 \quad$ "The degree supports us in order to work in a different way with our indigenous children. Through this course, we can revitalize our customs and strengthen our cultural identity as a whole.”

Academic $01 \quad$ "We are preparing our children to be someone in life hereafter: an indigenous chief, a councilor, a mayor, a governor of the state since we the Kaingang people, already have someone to take over as a councilor.”

Academic 05 "Certainly I believe that all indigenous communities can have a decent life and their rights deserve to be respected by the rulers of this country.”

Academic $08 \quad$ "We need to dream. That future generations are able to come to fight and seek better lives not only for the minority, but for the majority of indigenous peoples.”

Academic $09 \quad$ "We learned to impose ourselves the indigenous society as non-indigenous society by presenting ourselves as critical citizens.” 
As the mobilization of intercultural knowledge and its empowerment in emancipatory struggles, we must consider that in the face of a complex process of "recitations of historical and cultural narratives that reinvent temporalities and scenarios, in which indigenous both wins and loses much of its power in the founding myths of cultural dynamics” (Gadea, 2007: p. 157), indigenous teacher assumed a vital social role, since the reflection about education and educational practices is now carried out from other logic: the logic of dialogue between the traditional knowledge of their communities and knowledge historically legitimized by the formal school culture. It is therefore in this sense that the mediating role of these scholars, while teachers working in their ethnic territories, gains significance.

According to Mindlin (2003), the indigenous people after having their schools recognized, had to combine two different universes, theirs and the national society, that is, other ways of thinking and living. It seems to us that it is precise in dialogue with this need and conscious of their role as mediators in the community in which it operates. The Academic 06 highlights the important support that intercultural knowledge provides in the educational process of the indigenous child. According to him, through the course of intercultural degree, it is possible to "revitalize our customs and strengthen our cultural identity". Studying educational ways which may contribute to building the community that they crave for, and knowing their universe and also the cultural universe that surrounds them are the wishes that support the future projects for the Kaingang academic. When referencing the position of the border you live in an indigenous community, Skovsmose, Alro \& Valero (2009) emphasize that the motivation for student learning is linked to two issues: the background and the foreground of each individual. The background is related to cultural and socio-political roots of the individual or group, on the other hand, the foreground relates to the understanding of the perspectives of learning and living the sociopolitical context that apparently offers you; in other words, how these perspectives/future opportunities are observed by individual. Within this guideline reasoning stands in Bernardi (2011: p. 205):

[...] to teachers who work in educational processes proposed to the student. It's necessary to consider that all the action developed by them, as a trainer for or their continuing education, is only mobilized and produces meaning by the look that these teachers have thrown to the future.

From the speeches of our interlocutors, it was observed that the desired qualification in intercultural teaching by scholars/teachers, has support in "this look into the future" which encourages them constantly. According to the Academic 01, "We are preparing our children to be someone in life hereafter: a chief, a councilor, a mayor, a state governor, because we, Kaingang people, already have someone to take over as a councilor."

Each individual has his future projects. However, often these projects end up being interrupted or obstructed by lack of access to certain resources. The desire to change their reality motivates this group of indigenous students to fight for a better education, a decent life which dialogues with the tradition of ancient culture and the postmodern condition. Pursuing professional qualification was the strategy adopted by this group of Kaingang students. Here the movement between their background and their foreground can be noticed, as well as how their choices have contributed to assigning a meaning which is also political considering this level of training in higher education. The need to keep fighting for a fairer situation is constantly reaffirmed on their narratives.

In general, by focusing on expectations and looks about indigenous education produced by scholars of ethnicity Kaingang, enrolled in the Graduation Degree in Intercultural Indigenous in Pedagogy and Graduation Degree in Intercultural Indigenous in Mathematics and Natural Sciences, offered by the Unochapecó, we could see that what these scholars have inherited either as culture, tradition, or sense of identity as itself didn't broke up in the air, only moved, opened to question. That is, as part of a process marked by choices and expectations of the future, these scholars experience the constant need to mobilize efforts and build viable strategies to enroll in a context that transcends the boundaries of their community. However, at the same time their individual desires emerge from their speeches, from these ideas, also emerge from the desires of the group and the community to which they belong. In this sense, it is important to notice that the intercultural knowledge acquired by the indigenous students within a higher education institution, born and formed from socializing mechanisms of modernity on formal education, reflects a significant achievement in an environment that is inaccessible for them during a long time. However, what is clear to us is that for these academics, intercultural knowledge can be operated as an instrument of change, within and outside the Indigenous Area. The intercultural knowledge expands the debate about the role of formal education, indigenous school and teacher, in a space of constant cultural confluence. It is here that the indigenous "post-modernity" seems to reflect itself! 


\section{References}

Bauman, Z. (1998). O mal-estar das pós-modernidade. Rio de Janeiro: Jorge Zahar.

Bauman, Z. (2001). Modernidade Liquida. Rio de Janeiro: Jorge Zahar.

Bauman, Z. (2003). Comunidade: A busca por segurança no mundo atual. Rio de Janeiro: Jorge Zahar.

Bernardi, L. T. M. S. (2011). Formação continuada em matemática do professor indígena Kaingang: Enfrentamentos na busca de um projeto educativo. Ph.D. Thesis, Universidade Federal de Santa Catarina, Florianópolis. http://ppgect.ufsc.br/teses-e-dissertacoes.

Bhabha, H. K. (2003). O local da cultura. Belo Horizonte: Editora da UFMG.

Canclini, N. G. (1997). Culturas híbridas. Estratégias para entrar e sair da modernidade. São Paulo: EDUSP.

Gadea, C. A. (2007). Paisagens da pós-modernidade: Cultura, política e sociabilidade na América Latina. Itajaí: Universidade do Vale do Itajaí.

Hall, S. (1997). A centralidade da cultura: Notas sobre as revoluções de nosso tempo. Educação e Realidade. Porto Alegre, Vol. 22, 15-46.

Hall, S. (1999). A identidade cultural na pós-modernidade ( $3^{\mathrm{a}}$ ed.). Rio de Janeiro: DP \& A.

Hall, S. (2003). Da diáspora: Identidades e mediações culturais. Belo Horizonte: UFMG.

IBGE (2012). Os indígenas no Censo Demográfico 2010: Primeiras considerações com base no quesito cor ou raça. Diretoria de Estatística: Rio de Janeiro. http://www.ibge.gov.br/indigenas/indigena censo2010.pdf

Mindlin, B. (2003). Referências para a formação de professores indígenas: Um livro do MEC como bússola para a escolaridade. Brasília: Em Aberto.

Piovezana, L. (2007). A educação no contexto indígena Kaingang. In A. Nacke, (Ed.), Os Kaingang no oeste catarinense: Tradição e atualidade (pp. 101-122). Chapecó: Argos.

Skovsmose, O., Alro, H., \& Valero, P. (2009). “Antes de dividir temos que somar”: "Entre-Vistando" foregrounds de estudantes indígenas. Bolema, Rio Claro: São Paulo. Ano 22, n. 34, 237-262.

Unochapecó (2012). Alteração do projeto pedagógico do curso de licenciatura intercultural indígena para a criação do curso de licenciatura intercultural indígena em matemática e ciências da natureza. Chapecó, SC.

\section{Appendix: Questionnaires and Interviews}

\begin{tabular}{|c|c|}
\hline Questionnaires & Interviews \\
\hline \multicolumn{2}{|l|}{ 01. What would be the ideal school sought by your people for your children? } \\
\hline 02. What differentiates the indigenous schools of non-indigenous school? & Talk freely about: \\
\hline 03. What should change in your school? & $\begin{array}{l}\text { 1) Your and the Kaingang } \\
\text { people trajectory ; }\end{array}$ \\
\hline 04. In your opinion, what is your role as an indigenous teacher? & $\begin{array}{l}\text { 2) Why being a teacher; } \\
\text { 3) The Intercultural Indigenous }\end{array}$ \\
\hline 05. How far the course of Intercultural Indigenous Degree has been contributing in your formation? & $\begin{array}{l}\text { Graduation and its relationship } \\
\text { with the school and its students; }\end{array}$ \\
\hline $\begin{array}{l}\text { 06. In your opinion, what were the main changes observed with this graduation course? } \\
\text { a) In your professional career? } \\
\text { b) In your perception of Indigenous Education? }\end{array}$ & $\begin{array}{l}\text { and } \\
\text { 4) Your expectations about the } \\
\text { process of professional formation. }\end{array}$ \\
\hline
\end{tabular}


Scientific Research Publishing (SCIRP) is one of the largest Open Access journal publishers. It is currently publishing more than 200 open access, online, peer-reviewed journals covering a wide range of academic disciplines. SCIRP serves the worldwide academic communities and contributes to the progress and application of science with its publication.

Other selected journals from SCIRP are listed as below. Submit your manuscript to us via either submit@scirp.org or Online Submission Portal.
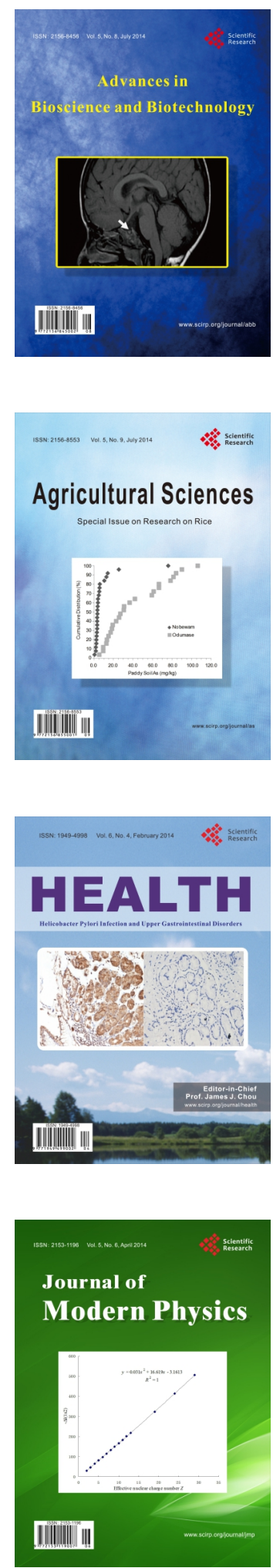
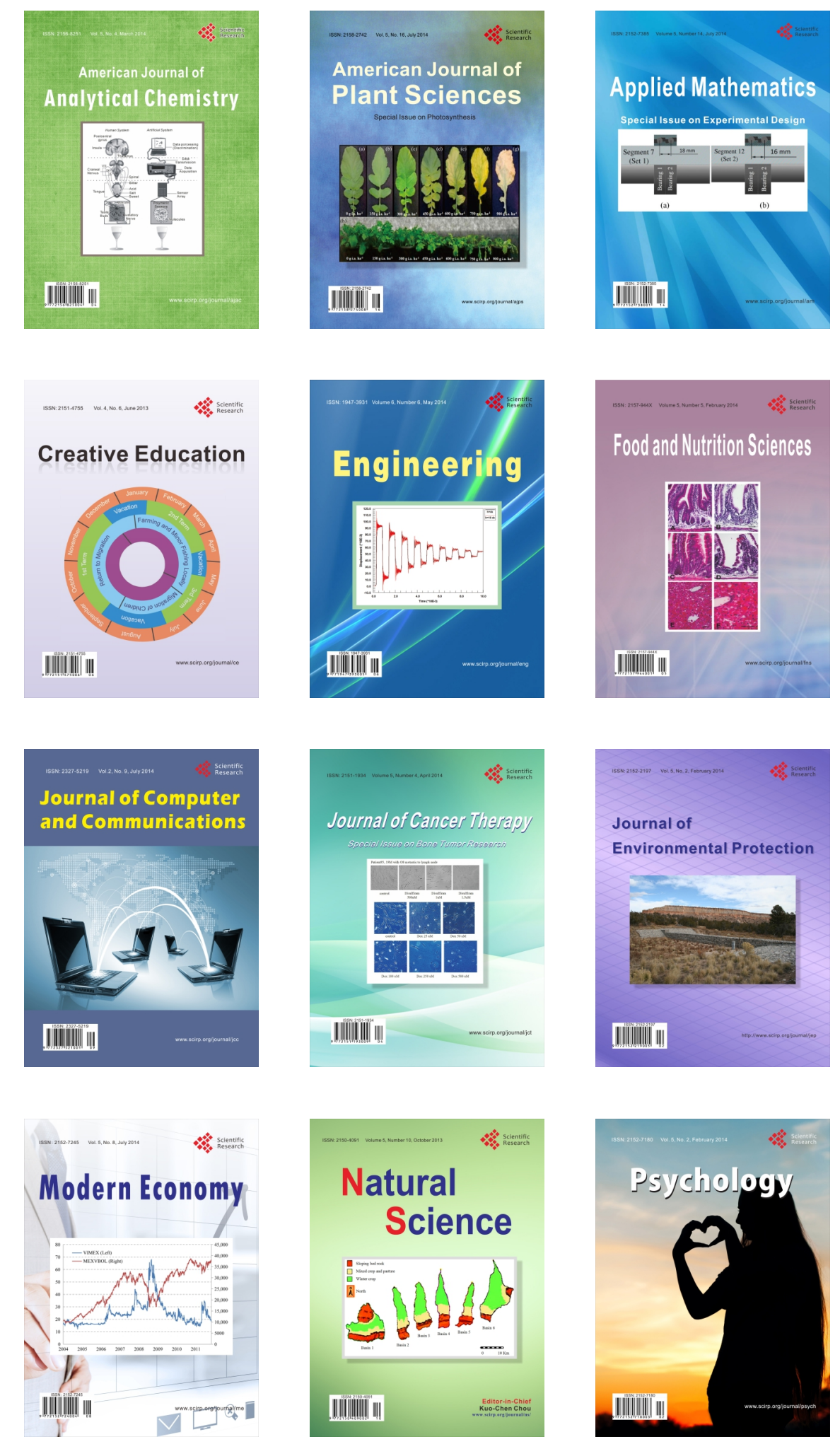